\title{
Petroleum Pump Price And Interest Rate On Food Prices In Nigeria: Ardl Approach
}

\author{
Rabiu Maijama'a ${ }^{1,2 *}$, Kabiru Saidu Musa ${ }^{1}$, Muktari Yakubu' ${ }^{1}$ and Shaibu Hassan Usman ${ }^{1}$ \\ ${ }^{1}$ M.Sc. Economics Students, Department of Economics, Faculty of Social and Management Sciences, Bauchi State University Gadau, \\ P.M.B 065, Yuli Campus, Bauchi State-Nigeria. \\ ${ }^{2}$ NNPC Retail Sales Representative, Nigeria National Petroleum Corporation, NNPC Tower, Central Business District, P.M.B 190, \\ Garki, Abuja-Nigeria. \\ Email: kabirusaidumusa@gmail.com \\ DOI: 10.29322/IJSRP.10.03.2020.p9930 \\ http://dx.doi.org/10.29322/IJSRP.10.03.2020.p9930
}

\begin{abstract}
This study investigate the impact of petroleum pump price and interest rate on food prices in Nigeria using an autoregressive distributed lag (ARDL) model covering the period 1984 -2018. The results showed that petroleum pump price and lending interest rate have positive and significant impact on food prices in both the long-run and the short-run whereas imports of goods and services appeared to be negative and significant in explaining changes in food prices in the long-run but is insignificant in the short-run. The exchange rate is insignificant in explaining changes in food prices in both the long-run and the short-run periods. The VECM Granger causality results indicates that there is a long-run causality in the petroleum pump price equation and short-run causality in food prices, petroleum pump price, interest rate, imports and exchange rate equations. The variance decomposition result indicates that variations in food prices and exchange rate are explained by petroleum pump price, imports of goods and services, and official exchange rate. While variations in imports and interest rate are explained by exchange rate and food prices. Therefore, government should re-establish lower legislated PMS pump price and Central Bank of Nigeria should also reduce the interest rate at which it lend money to commercial banks and that will make the commercial banks to lower their lending interest rate all in the process of achieving stability in food prices.
\end{abstract}

Keywords: Petroleum pump price, Interest rate, food prices, Exchange Rate, ARDL Approach and VECM Granger Causality

\subsection{Introduction}

In various oil importing nations within the Sub-Saharan Africa, the price of refined products of petroleum in addition to the changes in the rate of exchange are the input fundamentals engineering prices of domestic goods. In another words, increasing in prices of oil and fall in the value of legal tender are the famous external forces increasing food prices (Kargbo, 2018). Nigeria is like other nations where the domestic price of oil has been on the rising side ever since 1970s. Confront in the downstream section of the nations' petroleum section is a severe concern to most persons in the state. The occurrence has shown that adjustment in premium motor spirit (PMS) pump price has been on the raise (upward trend) since 1970. Among 1970 and 1980 it augmented from 3 kobo to 15 kobo, in 1981, it increased from 20 kobo to 70 kobo in 1990; but in 1991 it also increased from 70 kobo and reaches up to $\$ 22$ in the year 2000. Also, it was attuned upward in the year 2001 from $\$ 26$ until it reaches $\$ 97$ in 2013. Now from 2015 to 2019 it is stagnant at \#145 per liter (Roland, 2016). The connection between oil price swings and general prices are well recognized in literature. Most 
researchers found a positive correlation between oil price and inflation (Nwosu, 2009; Bombai, 2012; Umar and Lee, 2018; Orlu, 2017; Razmi et al, 2016; Mesagan and Olawale, 2016) while others found a negative association between oil prices and inflation (Alvalos, 2013; Dillon and Barrett, 2016; and Anthony, 2019; Umar and Muhammad, 2019; Aniekan et al, 2018) among others.

The key canal of transmission had been through prices of productive factors or inputs which in turn raises the cost of production. This is obvious as there is a reverse effect of oil price volatility for import dependent economy like Nigeria which suffers the effect of price increases that raises manufacture cost of foreign firms which is in turn transmitted to home prices. This leads to price adjustment on final goods as a result of alter in oil price. As an oil exporter, Nigeria earns enormous foreign exchange from crude oil export. Given the like between petroleum and foreign exchange earnings, the relationship between Nigeria and the rest of the world can easily be deduced. The petro-dollar accruing from crude export is usually monetized in the local currency which bloats the money stock. As a result, this affects money supply which has direct behavior on the inflationary force in the country Sikkam (1991) as cited in Anthony (2019). Inflationary weight in Nigeria has also been exacerbated by continual adjustments of domestic price of petroleum products.

Over the years, the extend between bank's deposit and lending rates remained unacceptably wide with adverse implications for savings mobilization and investment promotion. To achieve the preferred level of interest rate, the Central Bank of Nigeria (CBN) adopts various monetary policy apparatus and the key among which is the Monetary Policy Rate (MPR). The monetary policy rate before 2006 was known as the minimum Rediscount Rate (MRR) which implies the rate at which the Central Bank of Nigeria is eager to rediscount first class bills of exchange before its maturity (Onoh, 2007). He further stated that through increasing and decreasing the rate CBN is able to manipulate market price of funds. If the CBN increases or decreases the Monetary Policy Rate, banks' lending rates are projected to increase or decrease with it, showing a positive or negative relationships, in the history, the need to acquire certain group of assets as collateral safety to fine the CBN's discount window was dispensed because of global crisis Business Day (2009) as cited in Raymond (2014).

The significance of the study cannot be overemphasized. Firstly, the research will help to enlighten the decision makers on the nature of impact of domestic oil price and interest rate on increasing food prices in the oil exporting nation like Nigeria. Secondly, the study will serve as a contribution to the literature as well as to the methodology. Thirdly, the empirical result of the paper will be of huge significance to the government, to the private oil companies and the academy as a whole.

The objective of this investigate is to look at the impact of petroleum pump price and interest rate on food prices in Nigeria. Therefore, this explore intended to include to the literature on the impact of petroleum pump price and interest rate on food prices by employing an autoregressive distributed lag (ARDL) bound approach advanced by Pesaran, Shin and Smith (2001).

This research is prepared in sections. The first section is mainly centered on general introduction, the research problem, the significance of the study, the objective of the study and the organization of the paper. The second section contains the review of connected literature, which provides some proof from around the world and proof from Nigeria. The third section presents the data and the research methodology. The fourth section exposed the results and discussion of the findings. Finally, the fifth section discusses the summary, conclusions and the policy recommendations.

\subsection{Empirical Literature Review}

As mentioned earlier, studies on domestic oil price and food prices in Nigeria are very little. Therefore, the literature review is divided into impact of petroleum pump prices on food prices and the impact of interest rate on food prices.

\subsection{Petroleum pump price and food prices}

Nwosu (2009) look into the impact of fuel price on inflation in Nigeria using quarterly data series data spanning a time of 1995 to 2008 was analyzed. By means of Variance Autoregressive analysis to assess the relative contribution of fuel price on inflation, they results showed a positive connection between fuel price and inflation and therefore advocated that the policy of subsidizing fuel price should continue in Nigeria so as to help cushion the economy from the adverse effects of oil-price shock.

Bombai (2012) analyzed the association between petroleum prices and inflation in Nigeria. By paying attention to the impact of petroleum products prices increase on the Nigerian economy from the year 1990 to 2011. Employing the empirical econometric 
analysis approach and using variables like inflation rate and petroleum prices, the outcome shows that positive relationship exists between PMS, AGO and inflation. It though found PMS to exert higher effect on inflation than AGO, while negative link exists between inflation and DPK. The general effect clearly indicates that increase in petroleum product price contributes considerably to the rate of inflation in Nigeria.

Eregha et al. (2016) studied petroleum products prices and inflationary changes in Nigeria for the period of 1994 to 2012 . Using the Error Correction (ECM) Model to evaluate the secondary data, the results showed that there is high positive correlation between the prices of PMS and AGO and inflation in Nigeria. They advocate that government should put on hold that idea of removing subsidy on PMS for now and should center on deregulating the downstream sector to attract private investment with the aim of encouraging local refining of petroleum products instead of importing them

Arinze (2011) focused on the impact of oil price on the Nigerian economy. The study contends that growing adjustments of petroleum products prices have resulted in inflation, high cost of living, and inequitable income distribution in Nigeria between 1978 and 2007. It also found that the various Nigerian regimes increased fuel prices a total of 18 times within this period with most of the increase occurring between 1990 and 2007 where prices were adjusted, twice a year, sometimes. The study revealed that petroleum price spur inflation rate to increase also.

Umar and Muhammad (2019) examined the impact of oil price and exchange rate on food prices in Nigeria using secondary data spanning the period 1972 to 2016. Using Autoregressive Distributed Lag (ARDL) to analyze the data, the results showed that there is a long run association among the considered variables. The exchange rate is affecting food price more than the oil price counterpart since some of the food items are imported.

Okwanya et al (2015) examine the impact of fuel subsidy on consumer price index in Nigeria using secondary data from 1986 to 2014 on pump price of premium motor spirit and consumer price index. The Co-integration and Error Correction (ECM) Model were employed to analyze the data and the results found that the change in the fuel price does have short run impact on consumer price index. This implies that fuel subsidy reforms will not lower the real household income or increase poverty but could have permanent impact on the economy.

Ijeoma et al (2016) examines the effect of oil price on the volatility of food price in Nigeria. The time series data for the period of 2000 to 2013 were used. Using Co-integration test and VAR to analyze the data, the result for the co-integration test showed that there is no long run relationship between the variables where as the results from the VAR revealed a positive and significant short-run relationship between oil price and each of the selected food price volatility with the exception rice and wheat price.

\subsection{Interest rate and food prices}

Raymond (2014) examines the effect of changes in interest rate on inflation measured by CPI in Nigeria using both the descriptive and econometric methods. Set of data on money supply, interest rate, CPI, minimum rediscount rate, prime lending rate and treasury bills rate for the period of 1980 to 2010 were considered. The empirical results confirm that changes in interest rates and increase in the level of money supply were associated with rise in inflationary pressure. The study concludes that the relevant authority to correct abnormality in inflation rate through the introduction of appropriate interest rates from time to time.

Mbutor (2014) examine the relationship between inflation and money supply in Nigeria using Vector Error Correction (VECM) model to analyze the time series data on the variables spanning the periods of 1970 to 2012 on GDP, nominal exchange rate, maximum lending rate, inflation (i.e. CPI), broad money supply. The co-integration test results detected co-integration among the variables. The impulse response function showed a persistent positive relationship between inflation and money supply while variance decomposition of inflation shows that GDP was the strongest contributor to inflationary pressure in Nigeria, and that money supply accounts for up to 3.5 percent of aggregate price changes. 
Using secondary data on inflation rate, interest rate, net deposit credit and transfer payments for the period of 1981-2014. Babalola et $a l$, (2015) determines the effect of inflation rate and interest rate on economic growth. The study adopted Ordinary least squares (OLS) method of analysis. Long run relationship between the variables was established using Johansen integration test. The direction of causality and trend analysis was also performed on the variables. The result shows that inflation and interest rate has negative effect on economic growth but neither the inflation nor the interest rate granger causes economic growth. They recommended that policy makers should focus on maintaining inflation at a low rate (single digit) and ensuring interest rate stability.

Ifionu and Ibe (2015) investigated the impact of Inflation, Interest rate and Real Gross Domestic Product on stock prices of quoted companies on the Nigerian Stock Exchange (NSE). Times series data was used covering the period 1985-2012. The Johansen Multivariate Co-integration test indicates the existence of long-run equilibrium relationship among the variables in the model. There are no causal relationships between the variables based on the Granger Causality test result. Good fit for the model result indicates that $96.8 \%$ of variations in the dependent variable were as a result of changes in the independent variables. The findings suggest that inflation was the most important variable influencing stock prices in Nigeria.

Alexender et al, (2015) investigated the main determinants of inflation in Nigeria for the period of 1986-2011. The co-integration result reveals long run equilibrium relationship between the rate of inflation and its determinants. The Granger causality test revealed evidence of a feedback relationship between inflation and its determinants. The estimated VAR result showed that fiscal deficits, exchange rate, import of goods and services, money supply and agricultural output have a long run influence on inflation rate in Nigeria. Only lending rate influenced inflation in the short and long run horizon. The variance decomposition and impulse results shows that own-shock were significantly responsible for the variation and innovations in all the variables in the equation.

Amaefula (2016) examines whether long-run equilibrium relationship exist between interest rate and inflation in Nigeria. The data sets on interest rate and inflation covered the period 1995 to 2014. Johansen co-integration test was adopted to ascertain whether there is the existence of long run relationship between the two variables and vector error correction model (VECM) of granger causality was also employed to accommodate the long run and short run relationship and to find out whether the flow of relationship is bidirectional or unidirectional. The results show evidence of long-run equilibrium relationship between the two variables with strong evidence of unidirectional granger causality flow from interest rate to inflation rate at the long-run. The finding has empirical implication to monetary policy makers in areas of microeconomic planning in Nigeria.

Udoh and Isaiah (2018) estimate the dynamic model for inflation in Nigeria using quarterly data spanning 1995 to 2016. Four dynamic models: level lagged variables, differenced lagged variables, log-transformed lagged variables and differenced logtransformed lagged variables were considered. From the empirical results, the level form models performed better than the differenced form models. The level lagged model was the preferred model among the selected models. Predictions obtained from the model indicate that the model is stable as actual interest rate values, fall well within the computed $95 \%$ prediction interval. The study concludes that previous values of interest rate and money supply are significant in predicting future inflation rates in Nigeria.

Musa et al. (2019) estimate the impact of interest rate on inflation in Nigeria. The study make used of autoregressive distributed lag (ARDL) model on the time series data for the period 1970 to 2016. The ARDL results reveal that interest rate is inflationary in both the short run and the long run as it positively and significantly influencing inflation in the two periods.

Conclusively, all the relevant literature on Nigeria in this area generally focused on relating crude oil price and food price or economic growth, petroleum pump price and food prices, petroleum price, exchange rate and food price, interest rate and inflation. Nonetheless, interest rate specifically lending rate is expected to raise food prices. In line with this, this study seeks to fill this gap by testing the impact of petroleum pump price (particularly premium motor spirit) and interest rate on food prices.

\subsection{Research Methodology and Data}

The Nigeria's annual data employed by this study ranges from 1984 to 2018. The choice of the study period was based on the availability of data on the dependent and the independent variables. The data on interest rate, consumer price index, import of goods and services were sourced from World Development Indicators of World Bank while the petroleum pump price was obtained from Down Stream sector reports 2019.

This study employs Autoregressive Distributed Lag (ARDL) approach to co-integretion profounded by Pesaran (1997) and further modified and developed by Pesaran, Shin and Smith $(1999,2000)$ and also by Narayan (2005). This study adopted ARDL approach 
because of its comparative superiority over other approaches to co-integration this is because they require variables to be stationary at first difference, i.e. integrated of order I (1). However ARDL was developed to accommodate such circumstance. It can be used to analyses the data even if they are at different order of integration. Additionally it can also determine both the short run and long run co-integration among the variables of the study.

\subsection{Model specification}

It should be noted that this study involve a multi-variate analysis, that is involved four variables namely crude oil price, exchange rate, gross domestic products and oil revenue. Since the study is trying to examine the impact of crude oil price on exchange rate within the context of the Nigerian economy during the period under study, we have limit the number of variable to crude oil price, exchange rate, gross domestic products and oil revenue only, otherwise adding any variable may influence the result. To derive the model, it is known that based on the Quantity theory of money equation where demand for money is equated to the supply of money. Therefore, the equation can be written as: $\boldsymbol{M V}=\boldsymbol{P T}$

$$
T=\frac{M V}{P}=f\left(M V P^{-1}\right)
$$

Where: T will served as a measure of food prices (i.e. CPI), $M$ will be replaced with petroleum pump price (particular PMS price), $V$ will be replaced with lending interest rate (INR), $P^{-1}$ will be replaced with official exchange rate (EXR) and imports of goods and services (IMP) will be added in the model. Therefore, the model can be finally written as: $F P R=f(\mathrm{PMS}, \mathrm{INR}, \mathrm{EXR}, \mathrm{IMP})$

Following the above derived model equation of the study, the econometric log form of the model can be written as follows:

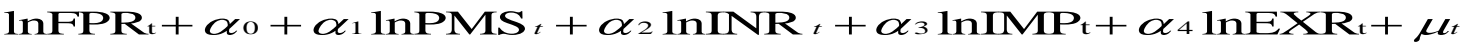

Where: $\operatorname{lnFPR} R_{t}$ is the natural $\log$ of food prices; $\operatorname{lnPMS} S_{\mathrm{t}}$ is the natural $\log$ of petroleum pump price; $\ln I N R_{t}$ is the natural $\log$ of interest rate; $\operatorname{lnEXR} \mathrm{t}_{\mathrm{t}}$ stand in for the natural $\log$ of exchange rate; $\ln I M P_{t}$ is the natural $\log$ of imports and $\mu_{t}$ is the error term.

\subsubsection{ARDL model}

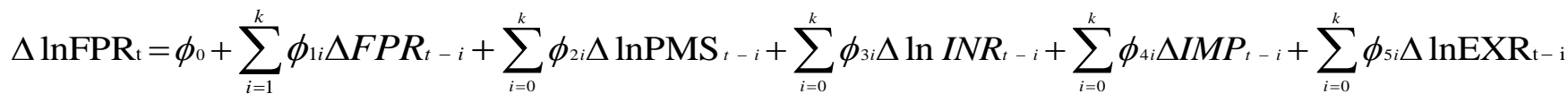
$+\alpha_{1} \operatorname{lnFPR}_{t-i}+\alpha_{2} \ln \mathrm{PMS}_{t-i}+\alpha_{3} \operatorname{lnINR}_{\mathrm{t}-\mathrm{i}}+\alpha_{4} \ln \mathrm{IMP}_{\mathrm{t}-\mathrm{i}}+\alpha_{5} \operatorname{lnEXR}_{\mathrm{t}-\mathrm{i}}+\varepsilon_{t}$

The following ARDL model provided in equation 1 above for the impact of petroleum pump price and interest rate on food prices, the model is divided into four sub models. The first one is the co-integration model, the second is the long-run model, the third is the short-run model and the fourth model is the short-run and error correction model.

\subsubsection{ARDL Co-integration model}


To test for the existence of long run relationship between variables of interest in the model equation is specified and estimated using ARDL bound test for co-integration. The model was specified together with the null and alternative hypotheses which may be rejected or accepted. This stand a turning point when the null hypothesis of no co-integration or no long run relationship between variables of the model is accepted, then some methods which includes vector error correction model (VECM) among others can be efficiently applied. If on the other hand there is an existence of long- run relationship due to the rejection of the null hypothesis, then short-run coefficients can be estimated. Thus, the specified model for co-integration is given in the equation 2 below:

$$
\begin{aligned}
& \Delta \operatorname{lnFPR}_{\mathrm{t}}=\phi_{0}+\sum_{i=1}^{k} \phi_{1 i} \Delta \operatorname{lnFPR}_{\mathrm{t}-\mathrm{i}}+\sum_{i=0}^{k} \phi_{2 i} \Delta \operatorname{lnPMS}{ }_{t-i}+\sum_{i=0}^{k} \phi_{3 i} \Delta \ln \operatorname{INR}_{t-i}+\sum_{i=0}^{k} \phi_{4 i} \Delta \operatorname{IMP}_{t-i}+\sum_{i=0}^{k} \phi_{5 i} \Delta \ln \mathrm{XXR}_{t-i} \\
& +\alpha_{1} \operatorname{lnFPR}_{t-i}+\alpha_{2} \ln \mathrm{PMS}_{t-i}+\alpha_{3} \operatorname{lnINR}_{t-i}+\alpha_{4} \operatorname{lnIMP}_{t-i}+\alpha_{5} \operatorname{lnEXR}_{t-i}+\varepsilon_{t}
\end{aligned}
$$

$$
\begin{aligned}
& H_{0}: \alpha_{1}=\alpha_{2}=\alpha_{3}=\alpha_{4}=0 \quad(\text { No } \text { Co }- \text { integ ration }) \\
& H_{1}: \alpha_{1} \neq \alpha_{2} \neq \alpha_{3} \neq \alpha_{4} \neq 0 \quad(\mathrm{Co}-\text { integ ration exists })
\end{aligned}
$$

\subsubsection{ARDL Long-run model}

Having the existence of long-run relationship between the variables of interest in the model then the estimation of the long run coefficients becomes necessary. To obtain the estimated long run coefficients, equation 6 below is correctly specified and estimated to obtain these coefficients.

$\operatorname{lnFPR}_{\mathrm{t}}=\alpha_{0}+\sum_{i=1}^{k} \alpha_{1 i} \operatorname{lnFPR}_{t-i}+\sum_{i=0}^{k} \alpha_{2 i} \operatorname{lnPMS}_{t-i}+\sum_{i=0}^{k} \alpha_{3 i} I N R_{t-i}+\sum_{i=0}^{k} \alpha_{4 i} I M P_{t-i}+\sum_{i=0}^{k} \alpha_{5 i} E X R_{t-i}+\varepsilon_{t}$

Where: $\alpha_{1}-\alpha_{4}$ are the short-run coefficients, $\Delta$ is the short-run sign $K$ is the maximum or optimum lag length and $\sum$ is the summation or sigma and $\varepsilon_{t}$ is the error term.

\subsubsection{ARDL Short-run model}

The equation 4 below is correctly specified and estimated in order to obtain the short-run coefficients of the variables.

$$
\Delta \operatorname{lnFPR}_{\mathrm{t}}=\phi_{0}+\sum \phi_{1 i} \Delta \operatorname{lnFPR}_{\mathrm{t}-\mathrm{i}}+\sum_{i=1}^{k} \phi_{2 i} \Delta \ln \mathrm{PMS}_{t-i}+\sum_{i=0}^{k} \phi_{3 i} \Delta \ln \operatorname{INR}_{t-i}+\sum_{i=0}^{k} \phi_{4 i} \Delta \ln \mathrm{IMP}_{t-i}+\sum_{i=0}^{k} \phi_{5 i} \Delta \ln \operatorname{lXR}_{t-i}+\varepsilon_{t}
$$

Where: $\phi_{1}-\phi_{4}$ are the short-run coefficients, $\Delta$ is the short-run sign $K$ is the maximum or optimum lag length and $\sum$ is the summation or sigma and $\varepsilon_{t}$ is the error term.

\subsubsection{ARDL short-run and error correction model:}


To obtain the short-run coefficients and the coefficient of error correction term which measure the speed of adjustment or convergence back to the equilibrium position from disequilibrium position, the equation 5 below was also correctly specified and estimated.

$\Delta \operatorname{lnFPR}_{\mathrm{t}}=\phi_{0}+\sum_{i=1}^{k} \phi_{1 i} \Delta \operatorname{lnFPR}_{t-i}+\sum_{i=0}^{k} \phi_{2 i} \Delta \operatorname{lnPMS}_{t-i}+\sum_{i=0}^{k} \phi_{3 i} \Delta \ln I N R_{t-i}+\sum_{i=0}^{k} \phi_{4 i} \Delta \ln \mathrm{IMP}_{t-i}+\sum_{i=0}^{k} \phi_{5 i} \Delta \operatorname{lnEXR}_{t-i}+\theta E C T_{t-1}+\varepsilon_{t}$

Where: $\phi_{1}-\phi_{4}$ are the short-run coefficients, $\theta$ is the coefficient of error term, $\Delta$ is the short-run sign $K$ is the maximum or optimum lag length and $\sum$ is the summation or sigma.

\section{Robustness Check Using Dynamic Ordinary Least Squares (DOLS) Fully (FMOLS) and Canonical Co-integration Regression (CCR)}

Modified Ordinary Least Squares

To gauge the long-run estimate, we apply Dynamic Ordinary Least Square (DOLS), Fully Modified Ordinary Least Square (FMOLS) and Canonical Co-integration Regression (CCR). DOLS and FMOLS have the power to deal with endogeneity problem, simultaneity bias and small sample bias. These estimators are good for robustness check of long-run ARDL estimates. DOLS and FMOLS have been advanced by Stock and Watson (1993) and Philip and Moon (1999), while CCR was advanced by Park (1992) respectively to address the problem of serial correlation and small sample bias that is applied to Ordinary Least Squares (OLS) estimator. The estimators can also be applied to mix order of integrated variables as far as there is an existence of long-run relationship between the variables of interest. Considering the powers of these analytical tools, their results will serve as robustness checks to ARDL long-run coefficients.

\subsection{Vector Error Correction Model (VECM) Granger Causality}

Having found long run relationship between variables, the direction of causality between the variables is also tested using Vector Error Correction Model. Sulaiman and Abdul-Rahim (2018) Maintained that VECM is considered to be efficient in testing the direction of the causality between the dependent and independent variables of interest when the variables moved together in the long run. Again, the methodology is considered the best for testing causality between variables of the same order of integration, that is, when they variables are stationary at first difference. Meaning they are I (1) variables. The Vector Error Correction Model (VECM) modeling equation within a system of Error Correction Model (ECM) for this study is given below: 
$\Delta \operatorname{lnFP} \mathrm{t}_{\mathrm{t}}=\alpha_{0}+\sum_{i=1}^{k} \beta_{1 i} \Delta \operatorname{lnFP}_{\mathrm{t}-i}+\sum_{i=1}^{k} \beta_{2 i} \Delta \ln \mathrm{PMS}_{\mathrm{t}-i}+\sum_{i=1}^{k} \beta_{3 i} \Delta \ln \mathrm{INR}_{\mathrm{t}-i}+\sum_{i=1}^{k} \beta_{4 i} \Delta \ln \mathrm{MPP}_{\mathrm{t}-i}+\sum_{i=1}^{k} \beta_{5 i} \Delta \ln E X R_{t-i}+\chi_{1} E C T_{t-1}+\mu_{1 t}$

$\Delta \operatorname{lnPMS}=\alpha_{1}+\sum_{i=1}^{k} \beta_{6 i} \Delta \ln \mathrm{PPR}_{\mathrm{t}-i}+\sum_{i=1}^{k} \beta_{7 i} \Delta \operatorname{lnPMS}_{\mathrm{t}-i}+\sum_{i=1}^{k} \beta_{8 i} \Delta \ln \mathrm{INR}_{t-i}+\sum_{i=1}^{k} \beta_{9 i} \Delta \ln \mathrm{IMP}_{t-i}+\sum_{i=1}^{k} \beta_{10 i} \Delta \ln E X R_{t-i}+\chi_{2} E C T_{t-1}+\mu_{2 t}$

$\Delta \operatorname{lnINR}_{\mathrm{t}}=\alpha_{2}+\sum_{i=1}^{k} \beta_{11 i} \Delta \operatorname{lnFPR}_{\mathrm{t}-i}+\sum_{i=1}^{k} \beta_{12 i} \Delta \operatorname{lnPMS}_{\mathrm{t}-i}+\sum_{i=1}^{k} \beta_{13 i} \Delta \operatorname{lnINR} \ln _{t-i}+\sum_{i=1}^{k} \beta_{14 i} \Delta \operatorname{lnIMP}_{t-i}+\sum_{i=1}^{k} \beta_{15 i} \Delta \ln E X R_{t-i}+\chi_{3} E C T_{t-1}+\mu_{3 t}$

$\Delta \operatorname{lnIMP}_{t}=\alpha_{3}+\sum_{i=1}^{k} \beta_{16 i} \Delta \operatorname{lnFPR}_{\mathrm{t}-i}+\sum_{i=1}^{k} \beta_{17 i} \Delta \ln \mathrm{PMS}_{\mathrm{t}-i}+\sum_{i=1}^{k} \beta_{18 i} \Delta \ln \operatorname{INR}_{t-i}+\sum_{i=1}^{k} \beta_{19 i} \Delta \operatorname{lnIMP}_{t-i}+\sum_{i=1}^{k} \beta_{20 i} \Delta \ln E X R_{t-i}+\chi_{4} E C T_{t-1}+\mu_{4 t}$

$\Delta \ln E X R_{\mathrm{t}}=\alpha_{4}+\sum_{i=1}^{k} \beta_{21 i} \Delta \ln \mathrm{FPR}_{\mathrm{t}-i}+\sum_{i=1}^{k} \beta_{22 i} \Delta \ln \mathrm{PMS}_{\mathrm{t}-i}+\sum_{i=1}^{k} \beta_{23 i} \Delta \ln \operatorname{INR}_{t-i}+\sum_{i=1}^{k} \beta_{24 i} \Delta \operatorname{lnIMP} \mathrm{MP}_{t-i}+\sum_{i=1}^{k} \beta_{25 i} \Delta \ln \mathrm{IXR}_{t-i}+\chi_{5} E C T_{t-1}+\mu_{5 t}$

Where the error correction term's coefficients are represented by $\chi_{1 t}-\chi_{5 t}$, the homoscedastic disturbance terms are denoted by $\mu_{1 t}-\mu_{5 t}$, the error correction term is denoted by $E C M_{t-1}$. The $E C M_{t-1}$ indicates both the long run causality and the speed of adjustment to long run equilibrium, while the Wald test statistic of the first-difference of the variables shows the short run causality and its direction.

\subsection{Results and Discussions}

This section presents the results of the estimation and discusses the findings of the study. The descriptive statistics are presented in Table 1 with the correlation analysis of the variables used in the study. It is observed that from Table 1 the average food prices, petroleum pump price and exchange rate are around 60.931, 46.729 and 96.075. While that of imports and interest rate are estimated to be around is 13.521 and 6.644 respectively. Three of the variables such as food prices, petroleum pump price and exchange rate are positively skewed as indicated by the positive skewed coefficients for the variables. Whereas imports and interest rate are negatively skewed. The study also tested for data normality using Jaque-Bera normality test. Four of the variables that include petroleum pump price, exchange rate, imports of goods and services and interest rate appear to be normally distributed as the P-values for Jarque-Bera test were greater than 0.05 for these variables. For the consumer price index variable, its P-value for the Jarque-Bera test was greater than 0.05 and it is therefore not normally distributed. Using correlation analysis, all the variables are in natural logarithm form. All the variables have positive correlation (i.e. between the independent variables and the dependent variables and even between the independent variables themselves) and the highest approximated value of correlation is between petroleum pump price and food prices. oil revenue and exchange rate which is 0.983 , followed by exchange rate and food prices which is given as 0.963 ; the lowest approximated value of correlation is between interest rate and petroleum pump price which is found to be 0.689 .

Table 1: Descriptive Statistics and Correlation Results.

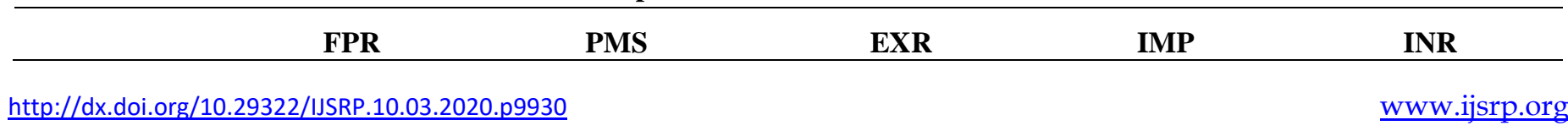




\begin{tabular}{cccccc}
\hline Mean & 60.931 & 46.729 & 96.075 & 13.521 & 6.644 \\
Median & 35.506 & 26.000 & 111.231 & 13.050 & 7.203 \\
Maximum & 240.142 & 145.000 & 306.083 & 22.811 & 11.064 \\
Minimum & 0.772 & 0.200 & 0.766 & 3.029 & 0.3166 \\
Skewness & 1.149 & 0.827 & 0.715 & -0.153 & -0.844 \\
Kurtosis & 3.399 & 2.345 & 2.910 & 2.605 & 3.301 \\
Jarque-Bera & $7.941(0.018)$ & $4.622(0.099)$ & $2.994(0.223)$ & $0.364(0.833)$ & $4.292(0.116)$ \\
Observation & 35 & 35 & 35 & 35 & 35 \\
lnFPR & 1.000 & & & & \\
lnPMS $_{\mathrm{t}}$ & 0.983 & 1.000 & & & 1.000 \\
lnEXR $_{\mathrm{t}}$ & 0.963 & 0.965 & 1.000 & & \\
lnIMP $_{\mathrm{t}}$ & 0.704 & 0.701 & 0.745 & 0.800 & \\
lnINR $_{\mathrm{t}}$ & 0.693 & 0.689 & 0.737 & & \\
\hline
\end{tabular}

Sources: Authors Computation using EViews 9; Note: Values in parentheses are the P-values.

To inspect the property of the data before conducting the estimation of the log-run model, the next are necessary. In the first step, we check the non-stationarity or integration properties of the time series data, using the extensively used augmented Dickey-Fuller (ADF) and Philip-Perron (PP) unit root tests, in the second pace, given that the variables are non-stationary. Table 2a presents the results of unit root test; using the augmented Dickey-Fuller (ADF) unit root test all the variables are stationary at level form, therefore they are all I(0) variables. But coming down to Philip-Perron (PP) unit root test also in Table 2a only official exchange rate and imports of goods and services that are stationary at level while food prices (FPR), petroleum pump price (PMS) and interest rate (INR) were stationary at first difference. Therefore, since there is a mixture of order of integration of the variables in Philip-Perron (PP) unit root test i.e. two variable are I (0) and three variables are purely I (1), while in the augmented dickey fuller unit root test all the variables are on the same order of integration i.e. I (1), then Autoregressive Distributed lag (ARDL) model is more competent to be useful as an investigative tool for this study.

Table 2a: Augmented Dickey Fuller Unit Root Test Result (ADF).

\begin{tabular}{|c|c|c|c|c|c|}
\hline & \multicolumn{2}{|c|}{ Level Values } & \multicolumn{2}{|c|}{ First Difference } & \multirow[b]{2}{*}{$\begin{array}{c}\text { Order of } \\
\text { Integration }\end{array}$} \\
\hline Variables & Constant & $\begin{array}{l}\text { Constant } \\
\text { \& Trend }\end{array}$ & Constant & $\begin{array}{l}\text { Constant } \\
\text { \& Trend }\end{array}$ & \\
\hline $\operatorname{lnFPR}_{\mathrm{t}}$ & $-3.035^{* *}(0.044)$ & $-4.498^{* * *}(0.006)$ & --------------- & --------------- & $\mathrm{I}(0)$ \\
\hline $\operatorname{lnPMS}_{\mathrm{t}}$ & $-4.130^{* * *}(0.003)$ & $-1.807(0.678)$ & - & ------------------ & $\mathrm{I}(0)$ \\
\hline $\operatorname{lnEXR}_{t}$ & $-2.935^{*}(0.051)$ & $-2.281(0.432)$ & & $\cdots$ & $\mathrm{I}(0)$ \\
\hline $\operatorname{lnIMP}_{t}$ & $-3.030^{* *}(0.042)$ & $-2.789(0.210)$ & - & --- & $\mathrm{I}(0)$ \\
\hline $\operatorname{lnINR}_{\mathrm{t}}$ & $-5.115^{* * *}(0.000)$ & $-4.139^{* *}(0.013)$ & ------------------. & -----------------. & $\mathrm{I}(0)$ \\
\hline \multicolumn{6}{|c|}{ hilip Perron Unit Root Test Result (PP). } \\
\hline Variables & Constant & $\begin{array}{l}\text { Constant } \\
\text { \& Trend }\end{array}$ & Constant & $\begin{array}{l}\text { Constant } \\
\text { \& Trend }\end{array}$ & $\begin{array}{l}\text { Order of } \\
\text { Integration }\end{array}$ \\
\hline $\operatorname{lnFPR}_{\mathrm{t}}$ & $-2.461(0.133)$ & $-0.629(0.970)$ & $-2.653^{*}(0.092)$ & $-2.874(0.183)$ & I (1) \\
\hline $\operatorname{lnPMS}_{\mathrm{t}}$ & $-1.959(0.302)$ & $-1.292(0.872)$ & $-4.206^{* * * *}(0.002)$ & $-4.928^{* * * *}(0.001)$ & $\mathrm{I}(1)$ \\
\hline $\operatorname{lnEXR}_{t}$ & $-3.753^{* * *}(0.007)$ & $-2.285(0.430)$ & 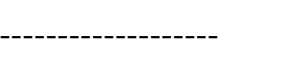 & 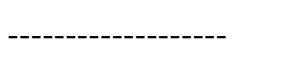 & $\mathrm{I}(0)$ \\
\hline $\operatorname{lnIMP}_{t}$ & $-5.317^{* * *}(0.000)$ & $-2.929(0.166)$ & ------ & --------- & $\mathrm{I}(0)$ \\
\hline $\operatorname{lnINR}_{t}$ & $-1.740(0.402)$ & $-2.064(0.546)$ & $-7.807^{* * * *}(0.000)$ & $-8.900^{* * * *}(0.000)$ & I (1) \\
\hline
\end{tabular}


Sources: Authors computation using EViews 9; Note: Values in parentheses are the P-values and ***,**\&* represents statistically significant at $1 \%, 5 \%$ \& $10 \%$ levels.

However, at times, ADF and PP tests may not produce dependable estimates if there is a existence of structural break in the variables and as such they could produce a biased result. To keep away from such doubt, we have equally engaged Zivot -Andrews structural break trended unit root test. Table $\mathbf{2 b}$ shows the results of Zivot -Andrews unit root test, which disclose that three variables out of the five variables i.e. food prices (FPR), petroleum pump price (PMS) and interest rate (INR) are stationary at level, meaning they are I(1) variables. Whereas the imports of goods and services (IMP) and official exchange rate (EXR) were not stationary at level form, but become stationary after first differencing, that is they are said to be $\mathrm{I}(0)$ variables. In a nutshell, This results indicates the mixture of $\mathrm{I}(1)$ and $\mathrm{I}(0)$ variables. Hence, the result of the Zivot-Andrews unit root test too supports the use of ARDL approach.

Table 2b. Unit Root Test Results Based on Zivot-Andrews.

\begin{tabular}{|c|c|c|c|c|c|c|c|c|c|}
\hline \multicolumn{4}{|c|}{ Level } & \multicolumn{4}{|c|}{ First difference } & \multirow[b]{2}{*}{$\begin{array}{l}\text { Break } \\
\text { point }\end{array}$} & \multirow[b]{2}{*}{$\mathbf{I}(\mathbf{d}$} \\
\hline Variables & Constant & $\begin{array}{l}\text { Break } \\
\text { Point }\end{array}$ & $\begin{array}{c}\text { Constant } \\
\text { \& trend }\end{array}$ & $\begin{array}{l}\text { Break } \\
\text { point }\end{array}$ & Constant & $\begin{array}{l}\text { Break } \\
\text { point }\end{array}$ & $\begin{array}{l}\text { Constant } \\
\& \text { trend }\end{array}$ & & \\
\hline $\operatorname{lnFPR}_{\mathrm{t}}$ & $-5.724^{* * *}(3)$ & 1993 & $-4.861^{* * * *}(3)$ & 1996 & -------------- & ------ & ---------- & ------ & $\mathrm{I}(0)$ \\
\hline $\operatorname{lnPMS} S_{t}$ & $-7.957^{* * *}(1)$ & 1992 & $-3.645(1)$ & 1994 & ------------- & ------ & ----------- & ------ & $\mathrm{I}(0)$ \\
\hline $\operatorname{lnEXR_{t}}$ & $-3.383(0)$ & 1999 & $-3.298(0)$ & 2000 & $-5.976^{* * *}(0)$ & 1990 & $-6.077^{* * *}(0)$ & 1991 & $\mathrm{I}(1)$ \\
\hline $\operatorname{lnIMP}_{t}$ & NA & NA & NA & NA & $-5.137^{* * *}(2)$ & 1999 & $-5.042^{* * *}(2)$ & 2005 & $\mathrm{I}(1)$ \\
\hline $\operatorname{lnINR} t$ & $-4.563(2)$ & 1992 & $-5.242^{* * * *}(2)$ & 1993 & ------------- & ------ & ------------- & ------ & $\mathrm{I}(0)$ \\
\hline
\end{tabular}

Source: Eviews 9; Note: ${ }^{* * *}$ stands for $1 \%$ level of significance and values in brackets are the lag lengths, while I(d) stands for the interpretation of the results.

Figure 1 present the choice of best lags in autoregressive distributed lag (ARDL) model co-integration equation based on the statement that residuals are serially uncorrelated. The research used most recent ARDL method to decide the best model. The Akaike Information Criteria (AIC) was used to identify the number of lags necessary in the model that is free from autocorrelation dilemma. The assessment found that ARDL 1,2,0,2,0 are the best number of lags necessary in our model that is a more consistent model.

Akaike Information Criteria (top 20 models)

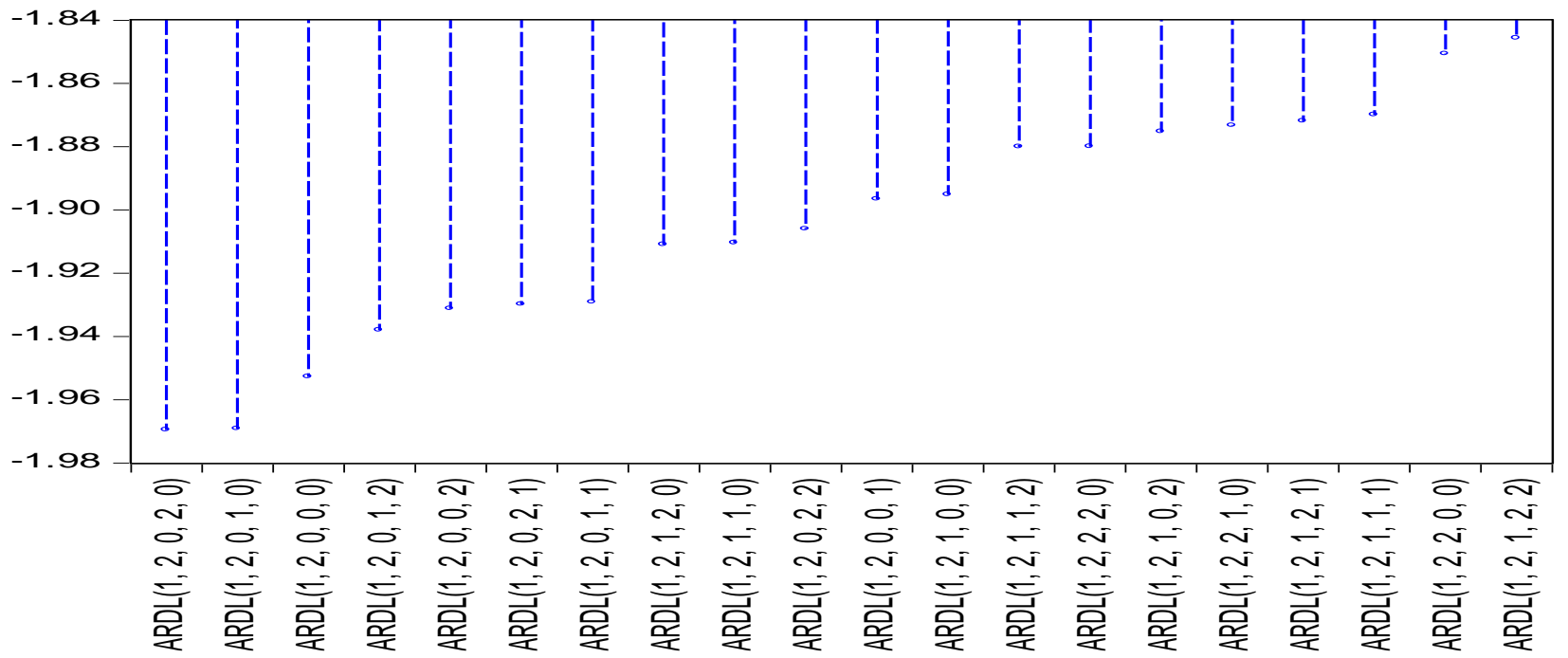

Figure 1: Optimum Lag Selection Criteria Graph 


\section{Co-integration Test}

Having recognized the best lag length, the next pace was to estimate the long-run connection among the variables by using ARDL Bounds test. The null hypothesis of no co-integration $\left(\mathrm{H}_{0}: \lambda_{1}=\lambda_{2}=\lambda_{3}=\lambda_{4}=0\right)$ was tested alongside the other hypothesis of the existence of a co-integration relationship ( $\mathrm{Ha}: \lambda_{1} \neq \lambda_{2} \neq \lambda_{3} \neq \lambda_{4} \neq 0$ ). The outcome of this test presented in Table 3 indicated that the null hypothesis of no co-integration relationship among the variables was rejected for the period under study (i.e. 1986 to 2018), at $1 \%$ level of significance which is more strong. The F-statistics value of 6.49 is higher than the lower bound value of 3.74 and the upper bound value of 5.06 of the critical values at the abovementioned level of significance. As such, a co-integration relationship exists in this respect. Meaning the variables are moving in the same direction or that they split an ordinary relationship in the long-run. This result corroborates the work of Umar and Muhammad (2019), Musa et al. (2019), Amaefula (2016) and Eregha et al. (2016) among others.

Table 3. Bounds Test Result

\begin{tabular}{|c|c|c|c|c|c|}
\hline \multirow[b]{3}{*}{ Model } & \multicolumn{5}{|c|}{ Bound test critical values } \\
\hline & \multicolumn{5}{|c|}{ [Unrestricted intercept \&no trend] } \\
\hline & F-stat. & Lag & $\begin{array}{c}\text { Level of } \\
\text { significance }\end{array}$ & I (0) & I (1) \\
\hline 1986 to 2018 & 6.49 & 2 & $1 \%$ & 3.74 & 5.06 \\
\hline 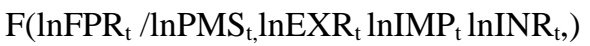 & & & $5 \%$ & 2.86 & 4.01 \\
\hline$K=4 \& n=35$ & & & $10 \%$ & 2.45 & 3.52 \\
\hline
\end{tabular}

Source: Author's Data Analysis 2020 Using Eviews 9.

The Johansen Juselius test for co-integration using representation with Trace statistics and representation with Max-Eigen value established the existence of 5 co-integration equations in the trace statistics representation and 2 co-integration equations in the maxeigen statistic representation. Therefore, we bring to a close that there is a long-run association among the dependent and independent variables and that the variables moved collectively in the long-run. The Johansen Juselius test for co-integration result supported the outcome of ARDL bounds test for co-integration.

Table 4: Johansen Juselius Test for Co-integration

\begin{tabular}{cccccc}
\hline $\begin{array}{c}\text { Hypothesized } \\
\text { No. of CE(s) }\end{array}$ & Eigenvalue & Trace Statistic & $\begin{array}{c}\mathbf{0 . 0 5} \\
\text { Critical Value }\end{array}$ & $\begin{array}{c}\text { Max-Eigen } \\
\text { Statistic }\end{array}$ & $\begin{array}{c}\mathbf{0 . 0 5} \\
\text { Critical Value }\end{array}$ \\
\hline C $=0$ & 0.703951 & $104.117^{* * *}(0.000)$ & 69.81889 & $40.168^{* * *}(0.007)$ & 33.87687 \\
$\mathrm{C} \leq 1$ & 0.595797 & $63.949^{* * *}(0.000)$ & 47.85613 & $29.892^{* *}(0.024)$ & 27.58434 \\
$\mathrm{C} \leq 2$ & 0.403924 & $34.056^{* *}(0.015)$ & 29.79707 & $17.073(0.168)$ & 21.13162 \\
$\mathrm{C} \leq 3$ & 0.274857 & $16.982^{* *}(0.029)$ & 15.49471 & $10.605(0.175)$ & 14.26460 \\
$\mathrm{C} \leq 4$ & 0.175722 & $6.377^{* *}(0.011)$ & 3.841466 & $6.377^{* *}(0.011)$ & 3.841466 \\
\hline
\end{tabular}

Sources: Authors Data Analysis 2020 Using EViews 9; Note: Values in parentheses are the P-values and ${ }^{* * *} \&{ }^{* *}$ represent statistically significant at $1 \%$ and $5 \%$ levels of significance. 
Following establishing a co-integration relationship between the variables, the long-run model in equation 3 and equation 4 were estimated to get the long-run and short run coefficients as offered in Table 5.the results revealed that PMS is positive and significant at 1 percent level of significance. Meaning that $\$ 1$ increase in PMS Price will lead to 0.731 percent increase in food prices in Nigeria and this is in line with the results of Bombai (2012), Nwosu (2009), Eregha et al, (2016), Arinze (2011), Orlu, 2017, Mesagan and Olawale, 2016, but contradicts the findings of Okwanya et al (2015), Aniekan et al, 2018 and Anthony, 2019. Exchange rate of naira is positive but insignificant in explaining the changes in the food prices within the period under study. This contradicts the results of Umar and Muhammad (2019) and Alexender et al. (2015). Imports of goods and services have negative and significant relationship with foods prices. Precisely a percentage change in imports of goods and services is associated with 0.378 percent decrease in foods prices in Nigeria. While lending interest rate is positive and significant in explaining the changes in food prices in Nigeria. Meaning that 1 percent increase in the lending interest rate is associated with 0.498 percent increase in food prices in Nigeria. This supported the findings of Raymond (2014), Alexender et al. (2015), Udoh and Isaiah (2018) and Musa et al. (2019).

Coming down to the short run results also in the Table 5, the results showed that current short run PMS Price is positive and significant in explaining changes in food prices and is supported by the work of Eregha et al. (2016) but contradict that of Okwanya et al. (2015). But PMS lag 1 is negative in explaining changes in the current year food prices. The short run exchange rate and imports of goods and services are insignificant in explaining changes in the dependent variables in the short run period. But lending rate of interest is positive and significant in explaining changes in the dependent variable food prices in Nigeria. Meaning that 1 percent increase in lending interest rate is associated with 0.189 percent raise in food prices in the short run period.

The R-square value of 0.998 signifies that 99 percent variation in the dependent variable can be jointly explained by the independent variables and only 0.1 percent variation that is explained by the other factors that not captured in the model or that are explained by the error term. The DW value of 1.504 indicates that the model is free from first order serial auto correlation as the value is within the range of 1.50 to 2.50 values. The F-statistic which is the test for the overall significant of the model is with the value of 1537.793 which is highly significant at 1 percent level of significance. Meaning that the all the independent variables in the model are jointly significant in explaining the changes in the dependent variable. The error correction value of -0.37 satisfied the econometrics requirements of negative value, less than one and significant which means that the feedback or convergence rate to long-run equilibrium as 37 percent. Precisely, the error correction term value also indicates that the long-run deviation from the food prices is corrected by 37 percent every year.

Table 5. Estimated long run and short run coefficients.

\begin{tabular}{lcc}
\hline $\begin{array}{l}\text { Dependent variable, } \operatorname{lnFPR}_{\mathrm{t}} \\
\text { Regressors }\end{array}$ & Coefficients & T-ratio (p value) \\
\hline $\operatorname{lnPMS}_{\mathrm{t}}$ & 0.731 & $9.890^{* * *}(0.000)$ \\
$\operatorname{lnEXR}_{\mathrm{t}}$ & 0.003 & $0.028(0.977)$ \\
$\operatorname{lnIMP}_{\mathrm{t}}$ & -0.378 & $-1.993^{* * *}(0.058)$ \\
$\ln \mathrm{NR}_{\mathrm{t}}$ & 0.498 & $3.722^{* * *}(0.001)$ \\
Constant & 1.668 & $3.905^{* * *}(0.000)$ \\
\hline
\end{tabular}

Dependent variable, $\Delta \operatorname{lnCPI} I_{t}$

$\begin{array}{lcc}\Delta \ln \mathrm{PMS}_{\mathrm{t}} & 0.121 & 2.296^{* *}(0.031) \\ \Delta \ln \mathrm{PMS}_{\mathrm{t}-1} & -0.132 & -2.242^{* *}(0.034) \\ \Delta \operatorname{lnEXR_{\mathrm {t}}} & 0.001 & 0.028(0.977) \\ \Delta \operatorname{lnMMP}_{\mathrm{t}} & -0.014 & -0.230(0.819)\end{array}$

http://dx.doi.org/10.29322/IJSRP.10.03.2020.p9930 


$\begin{array}{lcc}\Delta \ln I M P_{\mathrm{t}-1} & 0.077 & 1.202(0.241) \\ \Delta \operatorname{lnINR} \mathrm{t}_{\mathrm{t}} & 0.189 & 4.518^{* * *}(0.000) \\ \text { Constant } & 1.668 & 3.905^{* * *}(0.000) \\ \text { ECM }(-1) & -0.37 & -5.631^{* * *}(0.000)\end{array}$

$e c m=\operatorname{lnCPI}_{\mathrm{t}}-0.731 \times \ln \mathrm{PMS}_{\mathrm{t}}-0.003 \times \ln \mathrm{EXR}_{\mathrm{t}}+0.378 \times \ln \mathrm{IMP}_{\mathrm{t}}-0.498 \times \ln \mathrm{INR}_{\mathrm{t}}-1.668$

$\mathrm{R}^{2}$ : 0.998, DW-statistic: 1.504 , F-stat: $1537.793^{* * *}(0.000)$

Sources: Authors Data Analysis 2020 Using EViews 9; Note. ECM = Error Correction Model. ${ }^{* * *}{ }^{* *},{ }^{*}$ and ${ }^{*}$ are significant at $1 \%$ level.

To guarantee the consistency of the estimates, diagnostic tests of serial correlation, functional form, normality and the heteroskedasticity were conducted and reported in Table 6. The outcome showed that the null hypotheses for the serial correlation LM test, normality test and heteroskedasticity test could not be rejected with the exception of for the functional form or Ramsey Reset test for specification of the model.

Table 6. The Residuals of the Autoregressive Distributed Lag Diagnostic Tests.

\begin{tabular}{lcc}
\hline Test statistics & \multicolumn{1}{c}{ LM version } & F-version \\
\hline Serial correlation & CHQ $(2)=1.213[0.282]$ & $\mathrm{F}(1,22)=1.724[0.189]$ \\
Functional form & Not applicable & $\mathrm{F}(1,22)=7.512[0.011]^{* *}$ \\
Normality & CHQ $(2)=0.297[0.861]$ & Not applicable \\
Heteroscedascity & CHQ $(9)=8.369[0.497]$ & $\mathrm{F}(9,23)=0.868[0.565]$ \\
\hline
\end{tabular}

Note. The values in bracket are the probability values. $\mathrm{LM}=$ langrange multiplier test, $\mathrm{CHQ}=$ chi-square and ${ }^{* *}$ represent $5 \%$ significance level.

As recommended by Pesaran and Pesaran (1997), CUSUM meaning cumulative sum and CUSUMSQ meaning cumulative sum of squares tests for firmness of the model along the study were conducted. The results revealed in figures 2 shows that the residual is not within the 5 percent level of significance critical bound. Figure 3 demonstrates that the there is slight deviation of the residual from the 5 percent level of significance critical bound. Therefore, the overall model is unstable along the study period as the residuals were not inside the critical bounds at 5 percent level of significance.

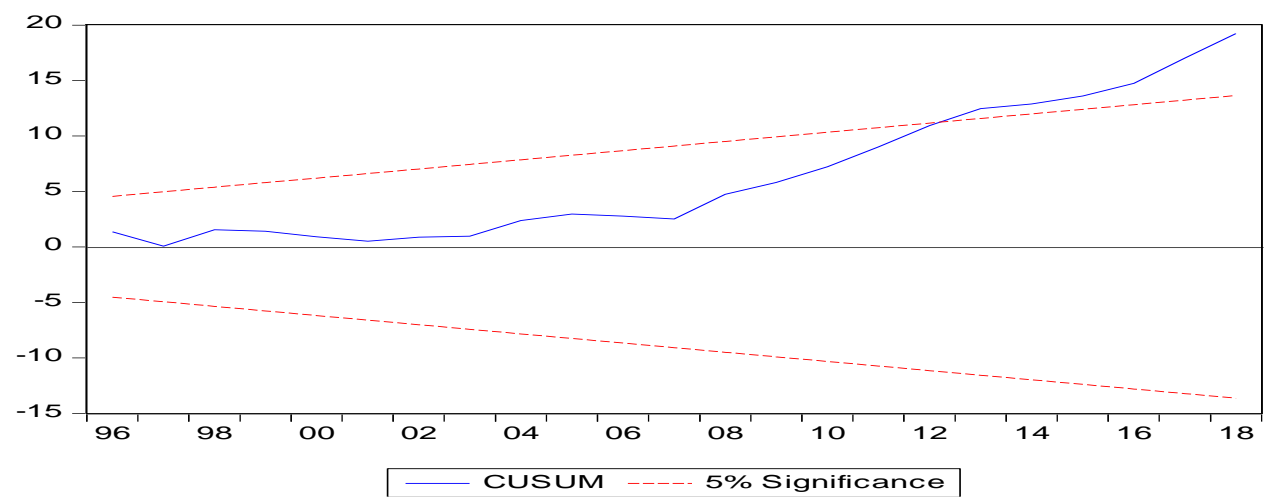

Figure 2. Plot of cumulative sum of residual for the model

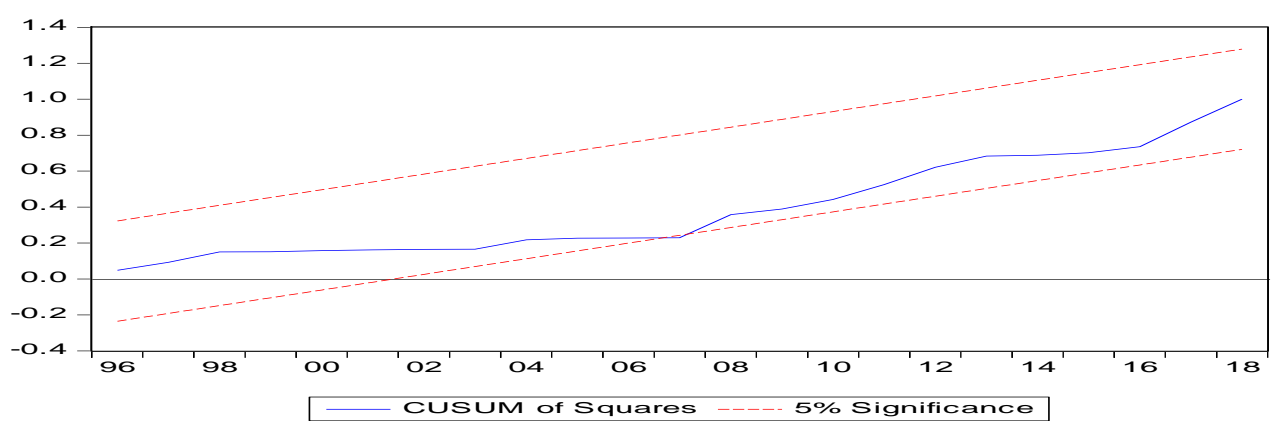

Figure 3. Plot of cumulative sum of squares for residual of the model. 
As robustness proves to the ARDL results, we have engaged dynamic DOLS, FMOLS and CCR, and their estimated results are reported in Table 8. The results show that in all the three estimators petroleum pump price has a significant positive impact on food prices, whereas exchange rate of naira is not statistically significant in explaining the dependent variable in DOLS and FMOLS results but with exception of CCR result which shows that it is positive and significant in explaining changes in the dependent variable. The imports of goods and services appeared to be negative and significant in DOLS result but shows positive and significant results in both FMOLS and CCR estimators. Lending interest rate appeared to be positive and significant under DOLS result only. The main focus of the study, which are petroleum pump price and interest rate, have been revealed to impact positive and significant on food prices as shown by the long run ARDL results and proof by the DOLS, FMOLS and CCR results.

Table 7. The Estimated Results for the Impact of petroleum pump price on food prices Using DOLS, FMOL and CCR

\begin{tabular}{|c|c|c|c|c|c|c|}
\hline \multirow{2}{*}{$\begin{array}{l}\mathrm{DV}=\operatorname{lnFPR} \mathrm{t}: \\
\text { Regressors }\end{array}$} & \multicolumn{2}{|c|}{ DOLS } & \multicolumn{2}{|c|}{ FMOLS } & \multicolumn{2}{|c|}{ CCR } \\
\hline & Coefficients & SE & Coefficients & SE & Coefficients & SE \\
\hline Long-run coefficients & & & & & & \\
\hline Petroleum Pump Price & $\begin{array}{l}0.686^{* * *} \\
(5.213)\end{array}$ & 0.131 & $\begin{array}{c}0.451^{* * * *} \\
(6.799)\end{array}$ & 0.066 & $\begin{array}{l}0.267^{* *} \\
(2.802)\end{array}$ & 0.095 \\
\hline Exchange Rate & $\begin{array}{c}0.142 \\
(0862)\end{array}$ & 0165 & $\begin{array}{c}-0.029 \\
(-0.298)\end{array}$ & 0097 & $\begin{array}{c}0.539^{* * *} \\
3647)\end{array}$ & 0147 \\
\hline Imports & $\begin{array}{l}-0.481^{*} \\
(-2.008)\end{array}$ & $\begin{array}{l}0.105 \\
0.239\end{array}$ & $\begin{array}{c}0.449^{* * *} \\
(3.316)\end{array}$ & 0.135 & $\begin{array}{l}(3.647) \\
0.306^{* *} \\
(2.142)\end{array}$ & 0.142 \\
\hline Interest Rate & $\begin{array}{l}0.519^{*} \\
(2.192)\end{array}$ & & $\begin{array}{c}0.038 \\
(0.463)\end{array}$ & & $\begin{array}{c}-0.006 \\
(-0.047)\end{array}$ & 0.145 \\
\hline Constant & $\begin{array}{l}1.158^{*} \\
(2.037)\end{array}$ & 0.236 & $\begin{array}{c}-0.333 \\
(-1.158)\end{array}$ & 0.082 & $\begin{array}{c}-0.264 \\
(-0.918)\end{array}$ & 0.288 \\
\hline
\end{tabular}

Note. Numbers in brackets are the t-statistics. DV = Dependent variable, DOLS = dynamic ordinary least squares; FMOLS = fully modify ordinary least square; $\mathrm{CCR}=$ Canonical Co-integration Regression, OLS = Ordinary Least Square; SE $=$ standard error. ${ }^{* * *} \&$ ${ }^{* *}$ indicates significant at $1 \%$ and $5 \%$ levels of significance respectively.

After the strength check of the long-run ARDL coefficients, then the causal relationship between the variables was examined by using Granger causality test of VECM in a vector autoregressive (VAR) system. The existence of co-integration as depicted by this study (refer to Table 3 and Table 4) propose the existence of a causal relation in at least one way. The estimated long run and short run causality results are presented in Table $\mathbf{8}$ and its summary in Table 9. The long run causality results reveal that $E C T_{t-1}$ in petroleum pump price equation has satisfied the econometric requirements of negative, less than one in value and statistically significant at 1 percent level of significance. This suggests that there is a long run causality running from lending interest rate, imports of goods and services, exchange rate and food prices to petroleum pump price. In the equation with lending interest rate as a dependent variable, the $E C T_{t-1}$ value is not negative even though it is less than one in value and significance, therefore we can conclude that there is no long run causality in any direction.

Beside the long run causality, the short run causality was also estimated. However, in the short run, there is bidirectional causality from running from imports of goods and services to food prices, from petroleum pump price to foods prices, from lending interest to petroleum pump price and from exchange rate to lending interest rate. The rest of the interpretations of the results is presented in Table 8 below.

Table 8. The Results of Vector Error Correction Model Granger Causality Direction of causality

Short - run $\quad$ Long-run




\begin{tabular}{|c|c|c|c|c|c|c|}
\hline $\begin{array}{l}\text { Dependent } \\
\text { Variables }\end{array}$ & $\sum \Delta \ln F P R_{t}$ & $\sum \Delta \operatorname{lnPMS} \mathrm{s}_{\mathrm{t}}$ & $\sum \Delta \ln E X R_{t}$ & $\sum \Delta \operatorname{lnIMP} P_{t}$ & $\sum \Delta \operatorname{lnINR} R_{t}$ & $E C T_{t-1}$ \\
\hline$\Delta \ln \mathrm{FPR}_{\mathrm{t}}$ & --- & $\begin{array}{c}20.798^{* * *} \\
(0.000)\end{array}$ & $\begin{array}{l}1.316 \\
(0.517)\end{array}$ & $\begin{array}{l}8.326^{* *} \\
(0.015)\end{array}$ & $\begin{array}{l}1.651 \\
(0.437)\end{array}$ & $\begin{array}{c}0.011 \\
(0.614)\end{array}$ \\
\hline$\Delta \ln \mathrm{PMS}_{\mathrm{t}}$ & $\begin{array}{c}19.299^{* * *} \\
(0.000)\end{array}$ & ---- & $\begin{array}{l}3.175 \\
(0.204)\end{array}$ & $\begin{array}{c}0.663 \\
(0.717)\end{array}$ & $\begin{array}{l}6.663^{* *} \\
(0.035)\end{array}$ & $\begin{array}{c}-0.312^{* * * *} \\
(0.005)\end{array}$ \\
\hline$\Delta \ln \mathrm{EXR}_{\mathrm{t}}$ & $\begin{array}{r}9.647^{* * * *} \\
(0.008)\end{array}$ & $\begin{array}{l}1.019 \\
(0.600)\end{array}$ & ---- & $\begin{array}{c}2.003 \\
(0.367)\end{array}$ & $\begin{array}{l}5.579^{*} \\
(0.061)\end{array}$ & $\begin{array}{l}-0.164 \\
(0.117)\end{array}$ \\
\hline$\Delta \operatorname{lnIMP} \mathrm{t}_{\mathrm{t}}$ & $\begin{array}{l}5.164^{*} \\
(0.075)\end{array}$ & $\begin{array}{l}5.589^{*} \\
(0.061)\end{array}$ & $\begin{array}{l}5.836^{*} \\
(0.054)\end{array}$ & --- & $\begin{array}{l}7.682^{* *} \\
(0.021)\end{array}$ & $\begin{array}{l}-0.078 \\
(0.415)\end{array}$ \\
\hline$\Delta \ln I N R_{t}$ & $\begin{array}{l}1.508 \\
(0.470)\end{array}$ & $\begin{array}{l}4.625^{*} \\
(0.099)\end{array}$ & $\begin{array}{l}9.178^{* *} \\
(0.010)\end{array}$ & $\begin{array}{r}5.650^{*} \\
(0.059)\end{array}$ & ---- & $\begin{array}{l}0.282^{* *} \\
(0.010)\end{array}$ \\
\hline
\end{tabular}

Diagnostic tests: Akaike information criteria $=-2.282$, VEC residual serial correlation LM test $=32.527(0.143)$, VEC

White heteroscedasticity test $=343.441(0.293)$, VEC Jarque Bera normality test $=0.948(0.622)$

Note. Values in parentheses are the P- values. $\mathrm{LM}=$ langrange multiplier; VEC $=$ vector error correction ${ }^{* *}$ indicates significant at $5 \%$ level.

The VECM diagnostic checks results are reported in the lower part of Table 9 which revealed that the model is steady and dependable as all the null hypotheses of the tests were accepted, and therefore its estimates are satisfactory for statistical deduction.

Table 9. The Summary of the Results of the Vector Error Correction Model Granger

Causality Approach

\begin{tabular}{|c|c|c|}
\hline Direction of causality & Short-run (F-statistics) & Long-run $\left(E C T_{t-1}\right)$ \\
\hline $\operatorname{lnPMS}_{\mathrm{t}}$ causes $\operatorname{lnFPR} \mathrm{R}_{\mathrm{t}}$ & At $1 \%$ level of significance & $\mathrm{NO}$ \\
\hline $\operatorname{lnEXR}_{t}$ causes $\operatorname{lnFPR} R_{t}$ & NO & NO \\
\hline $\operatorname{lnIMP}_{t}$ causes $\operatorname{lnFPR}_{t}$ & At $5 \%$ level of significance & NO \\
\hline $\operatorname{lnINR}_{\mathrm{t}}$ causes $\operatorname{lnFPR} \mathrm{R}_{\mathrm{t}}$ & NO & NO \\
\hline $\operatorname{lnFPR}_{\mathrm{t}}$ causes $\ln \mathrm{PMS}_{\mathrm{t}}$ & At $1 \%$ level of significance & At $1 \%$ level of significance \\
\hline $\operatorname{lnEXR}_{\mathrm{t}}$ causes $\ln \mathrm{PMS}_{\mathrm{t}}$ & NO & At $1 \%$ level of significance \\
\hline $\operatorname{lnIMP}_{\mathrm{t}}$ causes $\ln \mathrm{PMS}_{\mathrm{t}}$ & NO & At $1 \%$ level of significance \\
\hline $\operatorname{lnINR}$ causes $\ln P M S_{t}$ & At $5 \%$ level of significance & At $1 \%$ level of significance \\
\hline $\operatorname{lnFPR}_{t}$ causes $\operatorname{lnEXR_{t}}$ & At $1 \%$ level of significance & NO \\
\hline $\operatorname{lnPMS}_{\mathrm{t}}$ causes $\operatorname{lnEXR_{t}}$ & NO & NO \\
\hline $\operatorname{lnIMP}_{t}$ causes $\operatorname{lnEXR} t$ & NO & NO \\
\hline $\operatorname{lnINR}_{t}$ causes $\operatorname{lnEXR} R_{t}$ & At $10 \%$ level of significance & NO \\
\hline $\operatorname{lnFPR}_{\mathrm{t}}$ causes $\operatorname{lnIMP} \mathrm{P}_{\mathrm{t}}$ & At $10 \%$ level of significance & NO \\
\hline $\operatorname{lnPMS} S_{t}$ causes $\ln I M P_{t}$ & At $10 \%$ level of significance & NO \\
\hline $\operatorname{lnEXR}_{t}$ causes $\operatorname{lnIMP} P_{t}$ & At $10 \%$ level of significance & NO \\
\hline $\operatorname{lnINR}_{t}$ causes $\operatorname{lnIMP} P_{t}$ & At $10 \%$ level of significance & NO \\
\hline $\operatorname{lnCPI} I_{t}$ causes $\operatorname{lnINR}{ }_{t}$ & NO & NO \\
\hline $\operatorname{lnPMS} \mathrm{S}_{\mathrm{t}}$ causes $\operatorname{lnINR} \mathrm{R}_{\mathrm{t}}$ & At $10 \%$ level of significance & NO \\
\hline $\operatorname{lnEXR}_{t}$ causes $\operatorname{lnINR} R_{t}$ & At $10 \%$ level of significance & NO \\
\hline $\operatorname{lnIMP}_{t}$ causes $\operatorname{lnINR} R_{t}$ & At $10 \%$ level of significance & NO \\
\hline
\end{tabular}

Source: Author's Data Analysis 2020 using Eviews 9.

Variance Decomposition Test Results 
The predict error variance decomposition was used to estimate the short-run dynamic property of each of the variable originating from the shock in the arrangement. It is the fraction of forecast error variance for each variable that attribute to its own originality and to innovations in the other endogenous variables. The ordering of the variables in the variance decomposition is stated in Table 10a to $\mathbf{d}$ below over the same forecasting perspective for the short run period of five years.

\section{(i) Variance Decomposition of InFPR}

The variance decomposition for the natural log of consumer price index (lnCPI) shows that the elevated level of changes experienced by $\operatorname{lnFPR}$ is credited to its own shock at 100 percent in the first period and drop to 75.330 percent in the fifth period. The role of the other four variables is moderately marginal. The uppermost is by the natural log of imports (lnIMP), which start from 1.523 percent in the first period and continuation to increase up to 19.903 percent in the fifth period.

\section{(ii) Variance Decomposition of $\ln P M S$}

The natural log of petroleum pump price (lnPMs) displayed a related pattern where its own shock accounts for an unequal share of the total changes. The contribution of its own shock is around 81.922 percent in period 1 and continues to decrease until it reaches 38.680 percent in the last period. The involvement of the other four variables is also minor starting with the natural log of food prices (lnFPR) accounting for about 18.077 percent, 33.808 percent and 31.751 percent in period 1, 2 and 3, but decreases in the last two periods.

\section{(iii) Variance Decomposition of InEXR}

The variance decomposition of natural log exchange rate (lnEXR) has a similar pattern where by 93.147 percent variation in the exchange rate is explained by itself in the first period and it continue to decrease until it reaches 66.198 percent in the fifth period. Looking at the other four variables, the natural log of food prices (lnFPR) accounted for about 6.610 percent in the first period, but in the second period down to the fifth period, the natural log of petroleum pump price take the lead from natural log of consumer price index.

\section{(iv) Variance Decomposition of InINR}

The natural log of interest rate (lnINR) also displayed a similar pattern where its own shock accounts for a uneven share of the total variation. The contribution of its own shock is 87.792 percent in the first period and falls to 47.189 percent in the fifth period. The contribution of the other three variables is also trivial with the natural log of exchange rate (lnEXR) accounting for about 1.336 percent variation in the first period and continue to increase until it reaches 37.526 percent in the fifth period.

Table 10a: Variance Decomposition of lnCPI

\begin{tabular}{ccccccc}
\hline Period & S.E. & $\operatorname{lnFPR}$ & $\operatorname{lnPMS}$ & $\operatorname{lnEXR}$ & $\operatorname{lnIMP}$ & $\operatorname{lnINR}$ \\
\hline 1 & 0.073975 & 100.0000 & 0.000000 & 0.000000 & 0.000000 & 0.000000 \\
2 & 0.142232 & 97.88246 & 0.236112 & 0.357323 & 1.523680 & 0.000421 \\
3 & 0.211001 & 87.20022 & 2.477073 & 1.190459 & 9.106374 & 0.025873 \\
4 & 0.276299 & 79.27800 & 3.471157 & 1.649071 & 15.54406 & 0.057714 \\
5 & 0.323637 & 75.33002 & 2.614831 & 2.095752 & 19.90361 & 0.055786 \\
\hline
\end{tabular}

Source: Author's Data Using Eviews 9.

Table 10b: Variance Decomposition of InPMS

\begin{tabular}{rcccccc}
\hline Period & S.E. & InFPR & InPMS & InEXR & InIMP & InINR \\
\hline 1 & 0.240155 & 18.07702 & 81.92298 & 0.000000 & 0.000000 & 0.000000 \\
2 & 0.373567 & 33.80862 & 61.78388 & 3.262244 & 1.126555 & 0.018704 \\
3 & 0.461351 & 31.75143 & 52.80309 & 10.66964 & 1.294370 & 3.481459 \\
4 & 0.526569 & 28.71136 & 48.62317 & 9.127696 & 2.167586 & 11.37018 \\
5 & 0.590574 & 29.22795 & 38.68034 & 7.368544 & 2.093850 & 22.62932 \\
\hline
\end{tabular}

Source: Authors Data Using Eviews 9.

Table 10c: Variance Decomposition of $\operatorname{lnEXR}$

\begin{tabular}{rcccccc}
\hline Period & S.E. & $\operatorname{lnFPR}$ & $\operatorname{lnPMS}$ & $\operatorname{lnEXR}$ & $\operatorname{lnIMP}$ & $\operatorname{lnINR}$ \\
\hline 1 & 0.259518 & 6.610583 & 0.241833 & 93.14758 & 0.000000 & 0.000000 \\
\hline
\end{tabular}

http://dx.doi.org/10.29322/IJSRP.10.03.2020.p9930 


\begin{tabular}{lllllll}
\hline 2 & 0.369524 & 4.203364 & 8.550600 & 86.88541 & 0.004123 & 0.356499 \\
3 & 0.482450 & 9.888859 & 12.26078 & 75.39690 & 2.167346 & 0.286108 \\
4 & 0.602998 & 12.31696 & 13.14489 & 70.60217 & 2.878209 & 1.057767 \\
5 & 0.753747 & 11.15979 & 19.31252 & 66.19854 & 2.169419 & 1.159732 \\
\hline
\end{tabular}

Source: Authors Data Using Eviews 9.

Table 10d: Variance Decomposition of InIMP

\begin{tabular}{rcccccc}
\hline Period & S.E. & InFPR & $\operatorname{lnPMS}$ & $\operatorname{lnEXR}$ & $\operatorname{lnIMP}$ & $\operatorname{lnINR}$ \\
\hline 1 & 0.247140 & 0.915542 & 6.051715 & 1.257615 & 91.77513 & 0.000000 \\
2 & 0.302194 & 0.613357 & 4.311631 & 1.045040 & 92.93316 & 1.096808 \\
3 & 0.402050 & 0.645907 & 3.610228 & 11.89016 & 80.87874 & 2.974968 \\
4 & 0.474927 & 0.939555 & 3.724941 & 12.49070 & 79.68249 & 3.162317 \\
5 & 0.558967 & 0.678910 & 2.790801 & 12.91580 & 78.39202 & 5.222470 \\
\hline
\end{tabular}

Source: Authors Data Using Eviews 9.

Table 10e: Variance Decomposition of InINR

\begin{tabular}{rcccccc}
\hline Period & S.E. & InFPR & InPMS & InEXR & InIMP & InINR \\
\hline 1 & 0.346746 & 8.937794 & 1.170893 & 1.336875 & 0.761771 & 87.79267 \\
2 & 0.500647 & 5.919082 & 1.256387 & 18.21790 & 0.439178 & 74.16745 \\
3 & 0.627842 & 4.351775 & 1.234933 & 25.60948 & 5.226283 & 63.57753 \\
4 & 0.730675 & 3.234620 & 1.313995 & 31.96869 & 8.811184 & 54.67152 \\
5 & 0.821233 & 2.700793 & 1.752181 & 37.52615 & 10.83139 & 47.18948 \\
\hline
\end{tabular}

Source: Authors Data Using Eviews 9.

\section{Impulse Response Function Analysis}

The figure 4 illustrates the results of impulse response function analysis of natural log of food prices, natural log of petroleum pump price, natural $\log$ of lending interest rate and natural $\log$ of natural $\log$ of imports and natural $\log$ of exchange rate in the VAR system to one standard deviation shock. Given one standard deviation positive shocked to the natural log of food prices, the natural log of petroleum pump price response positively at a decreasing rate, natural log of exchange rate response negatively, natural log of imports responses positively and natural log of lending interest rate responses positively throughout the periods. Again given one standard deviation positive shock to the natural log of petroleum pump price, the natural log of food prices response negatively and afterward positively, the natural $\log$ of exchange rate response positively, the natural $\log$ of imports response negatively, the natural $\log$ of lending interest rate found to respond positively throughout the periods. Moreover given one standard deviation positive shocked to the natural $\log$ of exchange rate, the natural $\log$ of food prices response negatively from the start and positively at the end of the period and the same thing applies to natural log of petroleum pump price and natural log of imports, but the natural log of lending interest rate response positively throughout the periods. Furthermore given one standard deviation positive shocked to the natural log of imports, the natural $\log$ of food prices and natural log of exchange rate responses negatively and later positively for the rest of the periods, the natural log of petroleum pump price response by increasing at a decreasing rate, the natural log of lending interest rate response positively. Lastly, given one standard deviation positive shocked to the natural log of lending interest rate, the natural log of food prices and imports responses negatively, natural log of petroleum pump price and exchange rate response positively. 

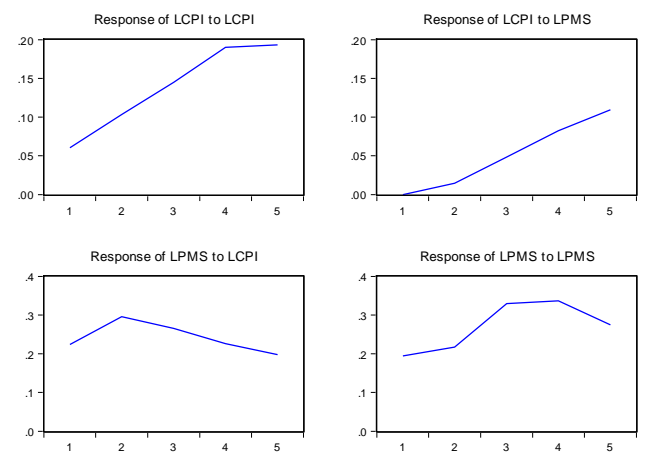

Response of LEXR to LCPI

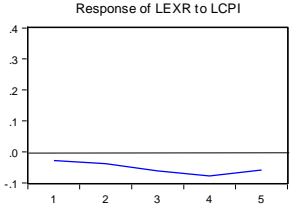

Response of LIMP to LCPI

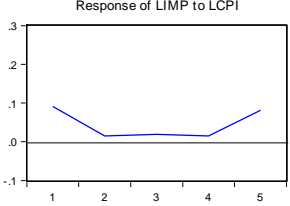

Response of LINR to LCPI

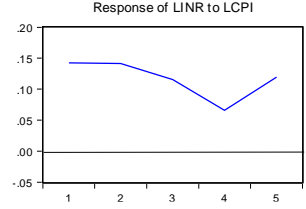

Response of LEXR to LPMS

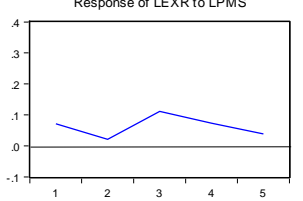

Response of LIMP to LPMS

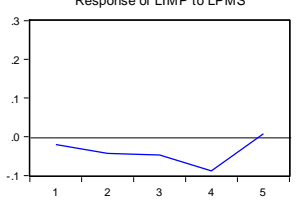

Response of LINR to LPMS

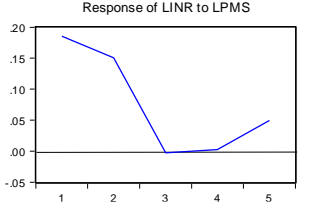

Response to Cholesky One S.D. Innovations

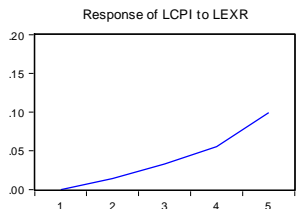

Response of LPMS to LEXR
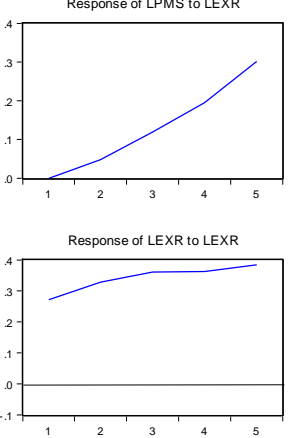

Response of LIMP to LEXR

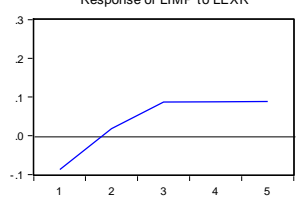

Response of LINR to LEXR

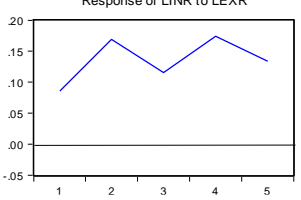

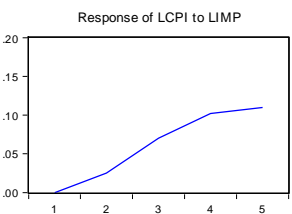
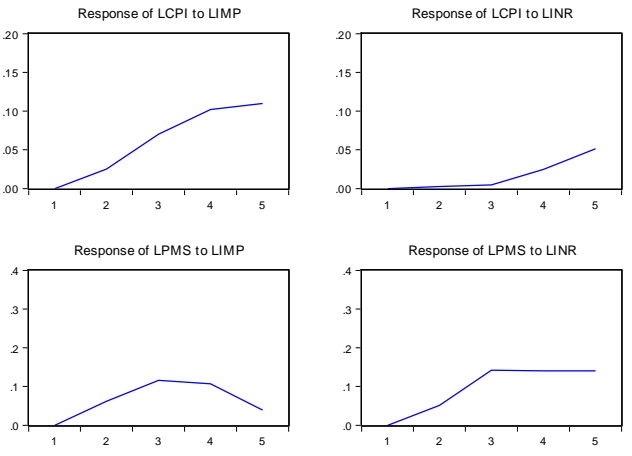

Response of LEXR to LIMP

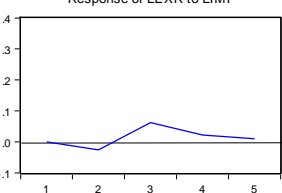

Response of LIMP to LIMP

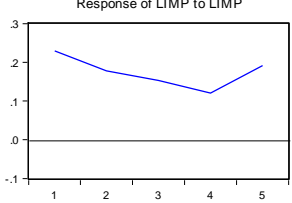

Response of LINR to LIMP

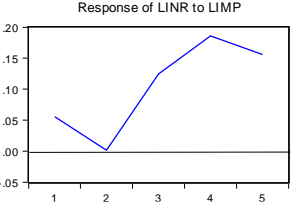

Response of LEXR to LINR

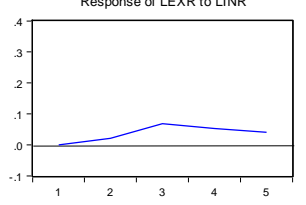

Response of LIMP to LINR

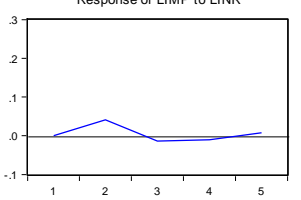

Response of LINR to LINR

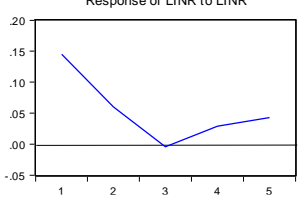

Figure: Impulse Response function Graphs

\subsection{Conclusion and Recommendations}

The study makes use of ARDL approach to co-integration to determine the impact of petroleum pump price and interest on inflation in Nigeria. The impact was tested based on the period of 1984 to 2018. The direction of causality was tested with the help of VECM Granger causality between the variables in both the short run and the long run periods. Firstly, the study tested for the existence of cointegration relationship after the optimum lag was identified and found that they variables were co-integrated. Following the cointegrated variables, the long-run model was also estimated and the results showed that petroleum pump price and lending interest rate are responsible for increase in food prices within the context of the study period. While imports of goods and services is found to be negatively related to food prices. Exchange rate is the only insignificant variable in explaining changes in food prices. Apart from the long-run estimation, the short-run model was also tested. The results showed that petroleum pump price and lending interest rate are significant in explaining changes in food prices in the short-run period while imports and exchange rate are not significant in explaining changes in food prices in the short-run. This implies that petroleum pump price and lending interest rate which are the focus of this research could influence food prices in both the long-run and the short-run periods. The reliability test were performed on the model and the outcome indicates that they model is good fit and have fulfilled nearly all the requirements for classical linear regression.

The checking for robustness was done using DOLS and FMOLS, and their outcomes corroborate the outcomes of long-run ARDL model. The VECM Granger causality was applied to test the direction of causality, which indicated a significant causality in the longrun in petroleum pump price model only, but in the short-run period, there was causality in food price, petroleum pump price, imports, exchange rate and lending interest rate models respectively. 
The results from variance decomposition revealed that the main sources of variation in the natural log of food prices are largely due to its own shocks and innovation in natural log of imports of goods and services while the leading sources of variation in natural log of petroleum pump prices are largely due to its own shocks and innovations in natural log of food prices. Also, the predominant sources of variation in natural log of exchange rate are due to shocks and innovations in natural log of petroleum pump price. Similarly, the biggest sources of changes in natural log of imports are due largely to own shock and innovation in the natural log of exchange rate. Again, the biggest sources of changes in natural log of interest rate are basically due to its own shock and innovation in the natural log of exchange rate.

The main recommendation from this research is that to achieve stability in food prices, there should reduction in petroleum pump price and lending interest rate since they have positive and significant impact on food prices in both the short-run and the long-run periods. From the side of the petroleum pump price, government should either imposed lower legislated price and sale it at lower prices or should privatized the sector in order to create competition among the privates competitors and realize lower price for the product. Central Bank of Nigeria should also reduce the interest rate at which it lend money to commercial banks and by doing that will make the commercial banks to lower their lending interest rate to the general public.

\section{References}

[1] Alexander, A. A., Andrew, H. A., and Danpome, G.M. (2015), Analysis of the Main Determinants of Inflation in Nigeria, Research Journal of Finance and Accounting, 6(2): 144-155.

[2] Alvalos, F. (2013) Do Oil Prices Drive Food Prices, In a Natural Experiment; Proceeding of the $6^{\text {th }}$ International Conference on Economic studies, July 22, 2011.

[3] Amaefula, C.G. (2016), Long-Run Relationship between Interest Rate and Inflation: $\quad$ Evidenec from Nigeria, IOSR Journal of Economics and Finance 7(3): 24-28.

[4] Aniekan, J. A., Namso, N. F. and Ubong, H. L. (2018) Petroleum Pump Prices Fluctuation and Agricultural Productivity in Nigeria: A Vector Error Correction Approach, London Journal of Research in Sciences: Natural and Formal, 18(2):1-16.

[5] Anthony, N. C. (2019) State-Space Analysis of Oil Prices and Consumer Price Index in Nigeria, International Journal of Innovative Finance and Economics Research 7(2):130- $\quad$ 141. Available at www.seahipaj.org

[6] Arinze, P.E. (2011), the Impact of Oil Price on the Nigerian Economy, JORIND, 9: 211- 215.

[7] Babalola, O.O., Dnalami, J.D., Akomolafe, K.J. and Ajiboye, O.P., (2015), Inflation, Economic Growth in Nigeria. European Journal of Business and Management, 7(30):

Interest Rates and

[8] Bombai, F.D. (2012), an Analysis of the Relationship between Petroleum Prices and 91-102.

International Journal of Business and Commerce, 1(12): 1-7.

Inflation in Nigeria,

[9] Dillon, Br. M., and Barrett, C. B. (2016), Global Oil Prices and Local Food Prices: $\quad$ Evidence from East Africa, American Journal of Agricultural Economics, 98(1), 154- 171. http://doi.org/10.1093/ajae/aav040

[10] Eregha, P.B., Mesagan, E.P. and Olawale, O.O. (2016), Petroleum Product Prices and Inflationary Dynamics in Nigeria, MPRA Paper No.70251.

[11] Ijeoma, C.N., Aye, G.C., and Asogwa, B.C. (2016) Effect of Oil Price on Nigeria's food Price Volatility, Cogent Food and Agriculture, 2:1146057. DOI: http://dx.doi.org/10.1080/23311932.2016.1146057

[12] Kargbo, B. I. B., (2018), Exchange Rate, Petroleum price and Price Determination in

Sierra Leon, AERC Research Paper 353, African Economic Research Consortium, Nairabi, pp 1-46. 
[13] Mbutor, O.M. (2014) Inflation in Nigeria: How Much is the Function of Money? Journal of International Finance, 6(1):21-27. http:// www.academijournals.org/JEIF
Economics

and

[14] Musa, K.S., Rabiu, M., Nasiru, M. and Sambo H.A. (2019) Interest Rate and Inflation Test Approach, Journal of Economics and Sustainable

Development, 10(20): 55-64.

Nexus: ARDL Bound

[15] Nwosu, C.P. (2009), Import of Fuel Prices on Inflation: Evidences from Nigeria, Bank of Nigeria.

[16] Okwanya, I., Moses, O. and Pristine, M.J. (2015) An Assessment of the Impact of Price Index in Nigeria, Global Journal of $\quad$ Interdisciplinary Social Science, 4(1): 36-39.

[17] Orlu, N.R. (2016) the Impact of Domestic Pricing of petroleum on Economic Growth of Nigeria, Global Journal of Social Sciences, 16, 2017:1-8. DOI: https://dx.doi.org/10.4314/gjss.v16i1.1

[18] Raymond, A.R. (2014) An Econometrics Analysis of Effect of Changes in Interest Rates International Journal of Economics, Commerce and Management, 2(10): 1-24. Available at http://ijecm.co.uk

[19] Razmi, F., Azali, M., Chin, L., and Shah, H.M. (2016), the Role of Monetary Transmission Channels in Transmitting Oil Price Shocks to Prices in ASEAN-4 581-591.

[20] Udoh, S.N. and Isaiah, S.A. (2018) a Predictive Model for Inflation in Nigeria, CBN Journal of Applied Statistics 9(2): 103-129.

[21] Umar, B. and Lee, C. (2018), Asymmetric Impacts of Oil Price on Inflation: An Empirical Study of African OPEC Member Countries, Energies, 11, 1-21.

[22] Umar, B. and Muhammad, M. A. (2019) Impact of Oil Price and Exchange Rate on Food of Economics and Sustainable Development, 10(8):51-56.

prices in Nigeria, Journal

\section{Author's Corner}

Rabiu Maijama'a: is a postgraduate student at the Department of Economics, Faculty of Social and Management Sciences, Bauchi State University, Gadau, Yuli Campus, Bauchi State of Nigeria and currently working with Nigeria National Petroleum Corporation (NNPC).

Kabiru Saidu Musa: is also a postgraduate student at the Department of Economics, Faculty of Social and Management Sciences, Bauchi State University, Gadau, Yuli Campus, Bauchi State-Nigeria.

Muktari Yakubu: is also a postgraduate student at the Department of Economics, Faculty of Social and Management Sciences, Bauchi State University, Gadau, Yuli Campus, Bauchi State- Nigeria

Shaibu Hassan Usman: is also a postgraduate student at the Department of Economics, Faculty of Social and Management Sciences, Bauchi State University, Gadau, Yuli Campus, Bauchi State - Nigeria.

http://dx.doi.org/10.29322/IJSRP.10.03.2020.p9930

Www.ijsrp.org 